\title{
COMPLIANCE TO RIVERBANK REGULATION GUIDELINES AND ITS IMPACT ON THE QUALITY OF RIVER ENYAU IN ARUA MUNICIPALITY, UGANDA
}

\author{
Geofrey Oloya* and Morgan Andama \\ Department of Biology, Faculty of Science, Muni University, P.O.Box 725, Arua, Uganda \\ *Corresponding Author: geofreyoloya3@gmail.com or mu0160110@muni.ac.ug
}

http://doi.org/10.35410/IJAEB.2019.4446

\begin{abstract}
This study documented the human activities carried out in the protected zones of river Enyau (within 30 m of river's bank) and their influence on the quality of the river. Human activities in the protected bank of river Enyau and the quality of the river were ascertained during a field survey in March-May, 2019.The diversity of macrozoobenthic invertebrates per site and water pollution levels were determined using Shannon-Weiner $\left(\mathrm{H}^{\prime}\right)$ and Biological Monitoring Working Party (BMWP) indices respectively. Fourteen different human activities dominated by housing units $(27 \%)$ were observed in river Enyau protected zones under study in Arua Municipality. Ozu-Ediofe zone corresponding directly to Arua urban center recorded the highest occurrence of the human activities (65.3\%) which greatly reduced the macrozoobenthic invertebrate diversity $\left(\mathrm{H}^{\prime}=1.2\right)$ and caused pollution of river Enyau $(\mathrm{BMWP}=26.0)$ along that zone. The downstream zones, Onduparaka $\left(\mathrm{H}^{\prime}=2.24, \mathrm{BMWP}=68.6\right)$ and Onduparaka-Ozu $\left(\mathrm{H}^{\prime}=1.57, \mathrm{BMWP}=46.9\right)$ sites were both moderately polluted. On the other hand, the upstream zones i.e. Ediofe-Pajulu Bridge $\left(\mathrm{H}^{\prime}=2.52, \mathrm{BMWP}=132.9\right)$ and Ragem Technical Institute $\left(\mathrm{H}^{\prime}=2.48\right.$, BMWP=96.2) were unpolluted and slightly polluted respectively. Hence, the implementation of the existing river bank management guidelines should be strengthened in Arua Municipality to ensure good quality of river Enyau and its sustainability.
\end{abstract}

Keywords: Arua Municipality, Compliance, Regulation guidelines, River banks, River Enyau.

\section{INTRODUCTION}

Freshwater sources such as rivers, streams, wells, springs, wetlands and lakes are the most available forms for human consumption and use yet they are also the most prone to pollution (DuPlessis, 2017). Most studies have shown that freshwater pollution emanates from unregulated human exploitation of the water resources for livelihood resulting from population and economic growth (Makoba, Shivoga, Muchiri, \& Miller, 2008; Rizkiyanti, Maizar, \& Hertika, 2013; Odonkor \& Addo, 2013; United Nations, 2015).

Uganda has been one of the fastest growing population in Africa (Lopes, 2016) and Arua Municipality in Uganda is a fast urbanizing town which has recently experienced a rapid population growth resulting into emergence of many economic activities (Abudu, Azo, \& Andogah, 2018). Reports show increasing trends of settlement and encroachment in the protected 
zones of river Enyau and the wetlands in Arua district to access water and land for economic activities(Atlas, 2016; Kansiime, Muwanga, \& Niwagaba, 2013;Abudu et al., 2018) despite the National Environment Regulations, NER (2000) of no human activity within 30 metres from the highest water mark on either sides of the river bank. The guideline also recommends the land owners surrounding the river to undertake conservation measures. However, there has been increasing settlement, animal grazing, brick making, washing bays and other emerging human activities in the river and its banks with some activities being carried out within less than 30 meters from the river (Atlas, 2016). Zziwa (2012) reported that the demand for water in Arua municipality surpassed production capacity of the water supply plant by $43 \%$ besides the inconsistent supply of water and inability of $30 \%$ of the people to pay for the piped water supplied by National Water and Sewerage Corporation (NWSC). More so, serious shortages of water have always hit Arua Municipality during the dry season. These are the additional factors causing the growing population of Arua Municipality to encroach on the protected banks of river Enyau with the resultant effect of pollution of the river.

The various human activities have greatly compromised the long term quality of the river which can be inferred using macrozoobenthic invertebrate assemblage whose life span is about a year or more implying that they can better integrate the receipts of contaminants to show general conditions of the local environment (Barbour, Gerritsen, Snyder, \& Stribling, 1999; Chapman et al., 1996). Therefore, the assemblage of macrozoobenthic invertebrates has been used for years by scientists as a biological monitoring tool to deduce the integrated physicochemical situations of lotic water bodies (Chapman et al., 1996). However, these macrozoobenthic invertebrates have not been used to infer the quality of river Enyau. This study therefore documented the human activities along the protected zones (i.e. within 30 metres on either sides of the river from the highest water mark) and their impact on the quality of river Enyau in Arua Municipality using macrozoobenthic invertebrate bioassessment.

\section{MATERIALS AND METHODS}

\subsection{Study Area}

The study was conducted along the section of river Enyau which flows through Arua Municipality (Figure 1). Arua Municipality is located in Arua district (03 01' North, 30 58' East, $120 \mathrm{~m}$ above sea level) in north western part of Uganda. River Enyau flows for about $72 \mathrm{Km}$ from its source at Uganda- Democratic Republic of Congo border through the western periphery of Arua town and empties downstream into river Nile (Albert Nile) (Kansiime et al., 2013). 


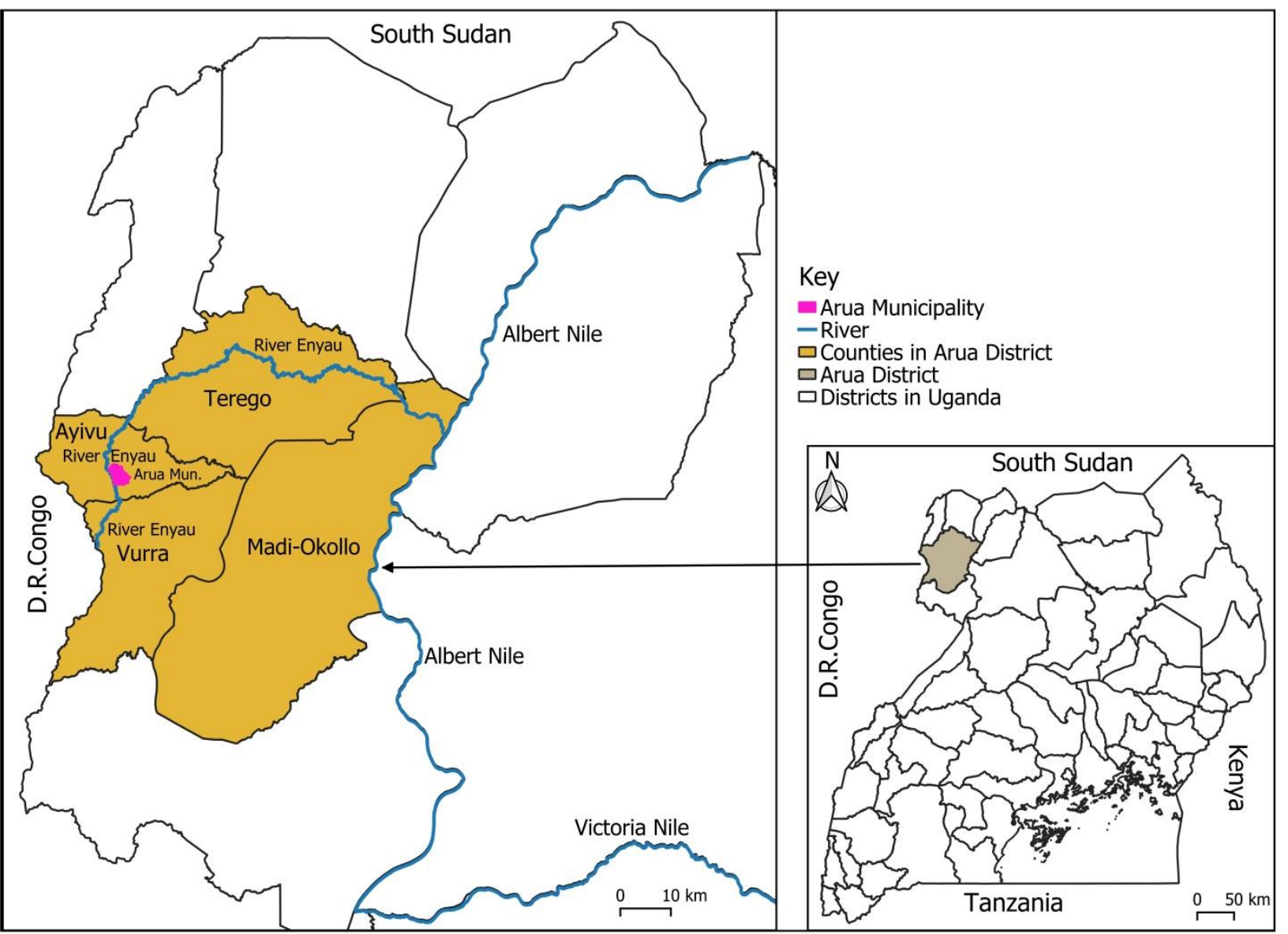

Figure 1: Map of Uganda showing the location of Arua District and River Enyau

Arua municipality receives a total annual rainfall between $900 \mathrm{~mm}^{3}$ to $1,500 \mathrm{~mm}^{3}$. The municipality experiences a bi-modal rainfall pattern with less rainfall between May and July. August and September are normally the wettest months which receive approximately $120 \mathrm{~mm}^{3}$ of rainfall. This normal pattern of rainfall has been fluctuating in the recent past with delayed rains in March and at times extended rainfall into December and January which are supposed to be dry. Temperatures in Arua municipality range from $21^{\circ} \mathrm{C}$ to $32^{\circ} \mathrm{C}$ and remain above $39^{\circ} \mathrm{C}$ in the dry season during the months of December to March (Arua District Local Government, 2012).

\subsection{Sampling}

The sampling was done during the period March-May, 2019along river Enyau bank extending upstream to Onduparaka bridge through Enyau village, Otrakutra village, Ozu cell, Opivu cell, Prison cell, Ediofe, Water supply, Bethany center, to Pajulu bridge. All kinds of human activities whose coverage were equal or greater than $10 \mathrm{~m}^{2}$ that were found in the protected zone of river Enyau were recorded during the field survey. Macrozoobenthic invertebrates found in river Enyau close to the human activities were also randomly sampled with similar collection efforts from diverse habitats in the river sampling sites called reaches. This was to ensure collection of representative samples for each zone of the river. 
Vol. 4, No. 05; 2019

ISSN: $2456-8643$

\subsubsection{Zonation of Sections of the River under Study}

The length of the river under study was divided into four zones based on their relative locations to Arua Municipality. Zone 1 was $2 \mathrm{Km}$ downstream Onduparaka bridge; Zone 2, upstream Onduparaka Bridge-Ozu Village; Zone 3, was from Ozu-Ediofe Bridge; Zone 4, between Ediofe bridge and Pajulu bridge. Each zone comprised of one or more villages and cells which included Onduparaka, Enyau village, Ozu cell, Adriko's cell, Opivu cell, Prison cell, Ediofe, Water supply, Bethany center, to Pajulu bridge respectively. The purpose of zoning the section of the river under study was to compare the most dominant human activities in the river bank protected area for the different zones.

\subsection{Human Activities in the Protection Zones}

The nature and frequency of human activities in the protected zones of the river (i.e. within 30 metres on either sides of the highest water mark of the river) were obtained during a field survey using a Checklist containing diverse list of human activities. It involved noting the number of times a particular activity occurred in the gazetted area with respect to each of the four zones, the spatial coverage of the activity, distance of the activity from the water body, types of contaminants released from the activity and mode of discharge.

\subsection{Macrozoobenthic Invertebrates Sample Collection}

The collection of macrozoobenthic invertebrates was based on the standard method recommended by Barbour et al., (1999) and Chapman et al. (1996) for wadable rivers and streams. Before starting to collect the invertebrates from the river, a reach (i.e. river length of about $100 \mathrm{~m}$ within a sampling site consisting of multiple representative habitats) was established in each zone. The reach was divided into ten $10 \mathrm{~m}$ equidistant transects from which eight transects were randomly selected for macrozoobenthos sampling. A standard D-frame dip net with mesh opening of $500 \mu \mathrm{m}$ and $0.3 \mathrm{~m}$ (1 foot) in width was used in the collection process. Starting from the transect downstream, one sample was sampled by positioning D-frame dip net in the river floor and disturbing the substrate upstream for a distance of $0.5 \mathrm{~m}$ from the net in a zig zag pattern. This disturbance comprised a single kick. A total of 20 kicks from variable habitats within a reach were considered adequate. They were combined in a container to comprise one homogeneous sample for each zone. Large debris were removed before the sample was transferred into a sample bucket. Macro invertebrates which remained stuck on the net were removed from the net using hands and pairs of plastic forceps. Sample containers were labelled indicating sample code, concentration of preservative, date and time, sample zone and name of the collector. The samples were preserved in $10 \%$ formalin and then transported safely to Muni University Science laboratory for processing. Field Data Sheet for Macrozoobenthos and Habitat Assessment sheets were also completed after sample collection.

\subsubsection{Sorting of Macrozoobenthic Invertebrates}

Before sorting the Macrozoobenthic invertebrates, the samples were soaked in water for 15 minutes and rinsed through a sieve net of mesh opening, $500 \mu \mathrm{m}$ to wash away the preservative. This was also to hydrate the samples and remove other fine debris. All the organisms and the debris from the sampled containers were removed and placed in a shallow pan with water to facilitate sorting. The organisms were sorted according to their different taxa and the sorted 
organisms placed in glass vials containing $70 \%$ ethanol preservative and labels containing the sample code, date, name of sample station and taxonomic group were put on the vial.

\subsubsection{Identification of Macrozoobenthic Invertebrates and Water Quality Indices}

The sorted organisms were classified to family level using identification keys from work of Birmingham et al., (2005), Gill, (n.d.) \& West Virginia Save Our Streams Field Guide to Aquatic Invertebrates, (n.d.). Biological Monitoring Working Party (BMWP) index which was adopted for analysis requires classification of invertebrates to family level. Cumulative counts of the families of the Macrozoobenthic invertebrates were tracked through tallying each taxon. The identified taxa were assigned sensitivity scores. Taxa with sensitivities of 0-5 have high pollution tolerance, 6-10 have moderate tolerance and 11-15 have low pollution tolerance (Gerber \& Gabriel, 2002b). BMWP and the Average Score per Taxon, ASPT (Hawkes, 1998; Walley \& Hawkes, 1997; Dickens \& Graham, 2002; Kaaya et al., 2015) at each site were computed. Water quality at a site as indicated by ASPT values was computed from total sum of sensitivities of taxa (Kaaya et al., 2015) divided by the total number of taxa at that site. The following interpretation of water quality basing on BMWP (Hawkes, 1998; Walley \& Hawkes, 1997) and ASPT (Aquilina, 2013; Dusabe et al., 2019) were adopted.

\section{5 Data Analysis}

A combination of descriptive and inferential statistics was used to analyze the data. Frequencies of human activities in the protected zone of river Enyau at the various sampling zones and the water quality for the different reaches along the river inferred using Shannon-Weiner diversity $\left(\mathrm{H}^{\prime}\right)$ of the macrozoobenthic invertebrates and BMWP-Average Score per Taxon (ASPT) indices per site were tabulated. Chi-square $\left(\chi^{2}\right)$ test was used to compare the extent of human activities in the study zones of the protected areas of river Enyau. Associations between human activities and water quality parameters were ascertained using Pearson correlation coefficient. Data analysis was done using SPSS ver 20, and PAST statistical packages and the obtained results were statistically significant at $\mathrm{p} \leq 0.05$.

\section{RESULTS}

\subsection{Human Activities in the Protected Zones of River Enyau}

Human activities were recorded in the protected zone (within 30 metres from the highest water mark on either sides of the river bank) in all the four zones of river Enyau catchment in this study though at different levels. Fourteen different human activities totaling to 400 counts from the four zones were documented (Table 1). Ozu-Ediofe Zone showed significantly the highest frequency of human activities of $65.3 \%$ (261) with all the diverse degrading activities present in the protected zones than the other zones $\left(\chi^{2}=346.06, \mathrm{df}=3, \mathrm{p}=0.00\right)$. However, Ediofe-Pajulu Zone (12.5\%), Onduparaka-Ozu (12\%), and Onduparaka Zone (10.2\%) showed relatively similar frequencies of the total number of activities in the river bank $\left(\chi^{2}=0.96, \mathrm{df}=2, \mathrm{p}=0.62\right)$. 
Table 1: Frequency of different Human Activities in River Enyau Protected Zones

\begin{tabular}{|lllllll|}
\hline Sn & Human Activities & Ozu-Ediofe & $\begin{array}{l}\text { Ediofe- } \\
\text { Pajulu } \\
\text { Bridge }\end{array}$ & $\begin{array}{l}\text { Onduparaka- } \\
\text { Ozu }\end{array}$ & $\begin{array}{l}\text { Onduparaka } \\
\text { Zone }\end{array}$ & Total \\
\hline 1 & Household & 81 & 21 & 2 & 4 & 108 \\
2 & Cultivation & 42 & 10 & 6 & 10 & 68 \\
3 & Open defecation & 30 & 4 & 24 & 4 & 62 \\
4 & Domestic Washing & 32 & 4 & 3 & 4 & 43 \\
5 & Sand Mining & 20 & 3 & 4 & 6 & 33 \\
6 & Livestock Grazing & 15 & 2 & 3 & 5 & 25 \\
7 & Latrines & 18 & 2 & 0 & 2 & 22 \\
8 & Brick Making & 11 & 2 & 4 & 2 & 19 \\
9 & Waste Disposal & 7 & 0 & 1 & 0 & 8 \\
10 & Washing Bay & 2 & 0 & 1 & 2 & 5 \\
11 & Agroforestry & 1 & 1 & 0 & 1 & 3 \\
12 & Bunding & 2 & 0 & 0 & 0 & 2 \\
13 & Terracing & 0 & 0 & 0 & 1 & 1 \\
14 & Water treatment & 0 & 1 & 0 & 0 & 1 \\
\hline & Total & 261 & 50 & 48 & 41 & 400 \\
\hline
\end{tabular}

Generally, households comprising of $27 \%$ (108) were found to be the most frequent of all the human activities in the protected areas (Table 1). The largest number of households were noted in Ozu-Ediofe Zone (81) followed by Ediofe-Pajulu Bridge Zone (21), with the least number in Onduparaka-Ozu. Cultivation, open defecation, domestic washing, sand mining, livestock grazing, latrines and brick making also generally occurred in large frequencies relative to other activities such as waste disposal and washing bay (Table 1). The most dominant human activities in Onduparaka Zone were; cultivation, sand mining and livestock grazing while in OnduparakaOzu, open defecation and cultivation were the most encountered. On the other hand, settlement, cultivation, domestic washing and open defecation dominated in Ozu-Ediofe while households and cultivations were the most common in Ediofe-Pajulu Bridge Zone. Cultivation was occurring predominantly in all the zones but was most dominant in Ozu-Ediofe Zone and least in Onduparaka-Ozu Zone. However, open defecation was noted to occur most frequently in OzuEdiofe followed by Onduparaka-Ozu and the least in Ediofe-Pajulu Bridge and Onduparaka Zone.

The various conservation measures (e.g. Agroforestry, Bunding, Terracing, Water treatment) were the least number of activities recorded in the protected zones (Table 1). The frequencies were 3 in Ozu-Ediofe Zone, 2 in Onduparaka Zone, 2 in Ediofe-Pajulu Bridge Zone and none in Onduparaka-Ozu zone.

Washing bays, domestic washing, disposed wastes and households were generally associated with discharge of similar wastes which included one or more of; washing chemicals like soaps 
and detergents, food wastes and oils. The mode of discharges was mostly point discharge and evidences of runoff showed indirect discharge of fecal matters from the open defecation fields and animal grazing points in the protected zones. Effluents from sewage treatment in Ozu-Ediofe Zone were witnessed flowing down the river. Sand mining and brick making were associated mostly with indirect discharge of soil into the river and causing river bank instability. Wastes from cultivations comprised mainly of plant residues which were dumped mostly at the river banks.

\subsection{Distribution of Macrozoobenthic Invertebrates in the Study Area in River Enyau}

Total number of individuals from each Macrozoobenthic Invertebrate taxon were summed up to obtain the abundance of macrozoobenthic invertebrates collected from River Enyau. This was used to calculate Relative Abundance. On overall, 511 macrozoobenthic invertebrates which composed of 35 families were collected (Table 2). Chironomidae (14.48\%), Cordulegasteridae $(13.89 \%)$ and Tipulidae $(11.15 \%)$ were the most abundant taxa followed by Baetidae $(9.20 \%)$ and Simulidae (9.00\%). Gammaridae, Leuctridae, Polycentropidae and Philopotamidae each of which comprised $0.20 \%$ were the least abundant.

The most diverse order was Trichoptera with 5 different families. Generally, all the sampled sites showed low diversity than the maximum expected $\left(\mathrm{H}^{\prime}=4.5\right)$. It ranged from $\mathrm{H}^{\prime}=1.20$ to $\mathrm{H}^{\prime}=2.50$ (Table 3). BMWP scores in Table 3 indicate that water quality from Ediofe-Pajulu bridge was unpolluted, Ragem Technical Institute was slightly impacted, while Onduparaka, OnduparakaOzu were moderately impacted while Ozu-Ediofe was polluted. Similarly, Average Score per Taxon, ASPT scores showed that the water quality between Ediofe-Pajulu bridge ranged from poor to moderate while the rest of the zones had poor water quality (Table 3). Meanwhile, a very strong positive correlation existed between ASPT values and Shannon-Weiner diversity ( $\mathrm{r}=0.83$; $\mathrm{N}=5 ; \mathrm{p}=0.08$ ) meaning that high macrozoobenthic invertebrate diversity is associated with good water quality (Table 3). Hence Ediofe-Pajulu Bridge zone had the highest macro invertebrate diversity $\left(\mathrm{H}^{\prime}=2.50\right)$ while Ozu-Ediofe Bridge zone recorded the least diversity $\left(\mathrm{H}^{\prime}=1.20\right)$. In site habitat Assessment, Ragem Technical Institute (89.0\%) and Ediofe-Pajulu bridge site (80.2\%) scored most and least in Ozu-Ediofe Bridge site (40.5\%). There was also a negative correlation between the frequency of activities in the protected zone and diversity of the invertebrates per site $(n=4, r=-0.75, p=0.25)$ despite being statistically insignificant.

Table 2: Distribution of Macrozoobenthic Invertebrates in River Enyau.

\begin{tabular}{|llll|}
\hline Order/Class & Family & Abundance & Relative Abundance (\%) \\
\hline Platyhelminthes & Planariidae & 6 & 1.17 \\
Mollusca & Hydrobiidae & 17 & 3.33 \\
& Physidae & 26 & 5.09 \\
Hirudinea & Planorbidae & 14 & 2.74 \\
Crustaceans & Hirudididae & 17 & 3.33 \\
Ephemeroptera & Gammaridae & 1 & 0.20 \\
& Baetidae & 47 & 9.20 \\
& Caenidae & 7 & 1.37 \\
& Siphlonuridae & 11 & 2.15
\end{tabular}




\begin{tabular}{|c|c|c|c|}
\hline \multirow{4}{*}{ Plecoptera } & Ephemerellidae & 9 & 1.76 \\
\hline & Leuctridae & 1 & 0.20 \\
\hline & Capniidae & 10 & 1.96 \\
\hline & Perlodidae & 4 & 0.78 \\
\hline \multirow{4}{*}{ Odonata } & Chloropalidae & 2 & 0.39 \\
\hline & Calopterygidae & 5 & 0.98 \\
\hline & Cordulegasteridae & 71 & 13.89 \\
\hline & Gomphidae & 4 & 0.78 \\
\hline \multirow[t]{4}{*}{ Hemiptera } & Corixidae & 2 & 0.39 \\
\hline & Nepidae & 2 & 0.39 \\
\hline & Notonectidae & 4 & 0.78 \\
\hline & Geridae & 2 & 0.39 \\
\hline \multirow[t]{4}{*}{ Coleoptera } & Dytiscidae & 4 & 0.78 \\
\hline & Gyrinidae & 4 & 0.78 \\
\hline & Dryopidae & 3 & 0.59 \\
\hline & Elmidae & 7 & 1.37 \\
\hline Alderflies & Sialidae & 2 & 0.39 \\
\hline \multirow[t]{5}{*}{ Trichoptera } & Polycentropidae & 1 & 0.20 \\
\hline & Phryganeidae & 2 & 0.39 \\
\hline & Hydroptilidae & 33 & 6.46 \\
\hline & Brachycentridae & 3 & 0.59 \\
\hline & Philopotamidae & 1 & 0.20 \\
\hline \multirow[t]{3}{*}{ Diptera } & Chironomidae & 74 & 14.48 \\
\hline & Simuliidae & 46 & 9.00 \\
\hline & Tipulidae & 57 & 11.15 \\
\hline Annelids & Annelidae & 12 & 2.35 \\
\hline Total & 35 & 511 & 100 \\
\hline
\end{tabular}

Table 3: Macrozoobenthic Invertebrate Diversity, BMWP and ASPT Scores for the Sites

\begin{tabular}{|c|c|c|c|c|c|c|c|c|}
\hline Site & $\begin{array}{l}\text { Number of } \\
\text { invertebrates } \\
\text { collected }\end{array}$ & $\begin{array}{l}\text { Number } \\
\text { of } \\
\text { families }\end{array}$ & $\begin{array}{l}\text { Shannon } \\
\text { Diversity } \\
\left(H^{\prime}\right)\end{array}$ & $\begin{array}{l}\text { Habitat } \\
\text { Assessment } \\
\text { score }\end{array}$ & $\begin{array}{l}\text { Dominant } \\
\text { family }\end{array}$ & $\begin{array}{l}\text { Total } \\
\text { BMWP } \\
\text { score }\end{array}$ & ASPT & $\begin{array}{l}\text { BMWP } \\
\text { Interpretation }\end{array}$ \\
\hline Onduparaka & 65 & 14 & 2.24 & $46.0 \%$ & $\begin{array}{l}\text { Hydrobiidae } \\
\text { (snails) }\end{array}$ & 68.6 & 4.9 & $\begin{array}{l}\text { Moderately } \\
\text { impacted }\end{array}$ \\
\hline $\begin{array}{l}\text { Onduparaka } \\
\text {-Ozu }\end{array}$ & 114 & 9 & 1.57 & $\mathbf{5 9 . 0 \%}$ & $\begin{array}{l}\text { Chironomid } \\
\text { ae (true flies) }\end{array}$ & 46.9 & 5.2 & $\begin{array}{l}\text { Moderately } \\
\text { impacted }\end{array}$ \\
\hline $\begin{array}{l}\text { Ozu-Ediofe } \\
\text { Bridge }\end{array}$ & 122 & 6 & 1.20 & $40.5 \%$ & Tipulidae & 26.0 & 4.3 & Polluted \\
\hline wwv & ijaeb.org & & & & & & \multicolumn{2}{|c|}{ Page 289} \\
\hline
\end{tabular}




\section{International Journal of Agriculture, Environment and Bioresearch}

Vol. 4, No. 05; 2019

ISSN: $2456-8643$

\begin{tabular}{|c|c|c|c|c|c|c|c|c|}
\hline $\begin{array}{l}\text { Ediofe- } \\
\text { Pajulu } \\
\text { Bridge }\end{array}$ & 144 & 22 & 2.52 & $80.5 \%$ & $\begin{array}{l}\text { Baetidae } \\
\text { (mayflies) }\end{array}$ & 132.9 & 6.0 & Unpollute \\
\hline $\begin{array}{l}\text { Ragem } \\
\text { Technical } \\
\text { Institute }\end{array}$ & 66 & 17 & 2.48 & $89.0 \%$ & $\begin{array}{l}\text { Cordulegaste } \\
\text { ridae } \\
\text { (Dragonflies) }\end{array}$ & 96.2 & 5.7 & $\begin{array}{l}\text { Slightly } \\
\text { polluted }\end{array}$ \\
\hline
\end{tabular}

BMWP Interpretation follows Hawkes (1998), Walley and Hawkes (1997); Paisley \& Trigg, \& Walley, n.d.

ASPT Water quality classification (Aquilina, 2013; Dusabe et al., 2019); 1-4 (very poor); 4-6 (poor); 6-9 (moderate); 9-12 (good); 12-15 (very good).

\section{DISCUSSION OF RESULTS}

\subsection{Human Activities in the Protected Zones of river Enyau}

A total of 393 counts of non-conservational human activities were found in River Enyau protected zones. This is in agreement with previous findings such as those by Adrapi, (2015); Atlas (2016), Kansiime et al., (2013) and WWF, World Bank \& NWSC(2018) except the extent of occurrence were not documented. However, this finding is contrary to the management policy which requires no activity in the protected river bank (NER, 2000). The most frequent human activities were noted along the surrounding zones directly in vicinity of the Municipality urban centers from Ozu cell to Ediofe. This could be attributed to high population growth rate of Arua Municipality (UBOS as cited in Abudu et al., 2018). As population increases, space and resources become limited and thus, people can be easily driven to earn livelihood from gazzetted places and resources. Cultivation was noted the second largest activity in the river bank protected areas. Arua District Local Government, (2012) described cultivation as the major economic activity in the Municipality which mostly take place in lowlands areas like river Enyau bank due to the fertile soil and favorable climate. Meanwhile, USMID, (2012) Report expounded that lack of adequate funding to the environmental departments of the Uganda Municipalities resulted into poor implementation of the protection guidelines. This was evidenced by very few number of conservation measures aimed at protection of the river bank. Still, it could also result from less consideration of environmental matters in drawing Municipal infrastructural strategic development plan.

Consequently, the types of wastes and mode of discharge which included fecal matter, soap and detergents, oils, animal wastes, food remains and plant residues were documented in this study most of which discharge wastes directly into the river. These were greatly similar to the findings of the previous studies (Adrapi, 2015; Kansiime et al., 2013).

\subsection{Distribution of Macrozoobenthic Invertebrates in the Study Area in River Enyau}

Disturbances caused by the human activities are majorly responsible for the change or differences in the macrozoobenthic assemblage depending on their varying sensitivity to water pollution (Gerber \& Gabriel, 2002). The high Chironomid abundance compared to the other 
Macrozoobenthic Invertebrate families is attributed to their very high colonization potential and adaptability to a range of habitats (Rádková et al., 2014) as pollution tolerance of the Macrozoobenthic invertebrates varies with taxa sensitivities (Gerber \& Gabriel, 2002a).

Water quality of most sites sampled were found to have been impacted except Ediofe-Pajulu Bridge (BMWP Score,132.9) and Ragem Technical Institute Sites (BMWP Score, 96.2) based on the BMWP Scoring System designed by Walley and Hawkes, (1997). According to Clement, Trust and Paper (2017), low riparian vegetation cover and sandy sediment substrates contribute to low distribution of macrozoobenthic invertebrates. The findings of Kasangaki et al., (2008) and Okot-Okumu et al., (2004) further expounded on the effectiveness of forested river bank buffer in ensuring good water quality. In the context of this study, activities such as settlement, sand mining, brick making and cultivation disrupted river bank and riparian vegetation growth, caused new sediment deposition and unstable river bank in some sites (Habitat assessment score, Table 3). This interrupts natural temperature regime and suitable stream health which contribute to low diversity of macrozoobenthos (Kasangaki et al., 2008). Further, activities such as waste disposal, defecation, washings and latrines in the river bank can be discharged / discharge their wastes into the water through runoff. Such discharges can cause change in the physico-chemical properties of water (Rizkiyanti et al., 2013). Thus, low diversity in macrozoobenthic invertebrates in sites such as Ozu-Ediofe and Onduparaka-Ozu could have been caused by accumulation of the chemicals that interrupts the organisms' lifecycle and organic deposition which leads to low dissolved oxygen. As a result, it can cause death or migration of the more sensitive organisms and dominance of less sensitive organisms (Barbour et al., 1999). The dominance of chironomid larvae in Onduparaka-Ozu zone indicates pollution as chironomid larvae are highly tolerant to pollution (Rádková et al., 2014). Sites such as Ediofe-Pajulu Bridge and Ragem Technical Institute which showed higher distributions of the invertebrates could be attributed to many factors. Firstly, the immediate riparian zones and river bank comprised mostly of native vegetation cover in Ragem Technical institute site while Ediofe-Pajulu bridge site have been surrounded by agroforests some of which were planted by NWSC. Evidences of bank failure and erosion were minimal. Epifaunal substrate consisted fairly of even mix of habitat materials with snags, undercut banks, mat roots, gravel and sand. These could have provided good colonization potential of invertebrates thus higher habitat assessment score (Table 3). Secondly, it could be explained by relatively fewer human activities in the protected river bank (Elhaj, Garbo, \& Chapeta, 2015; Miebaka, 2018). The improving trend of water quality downstream after Ozu-Ediofe zones could be as a result of buffering effects of the riparian and river bank vegetation downstream (Kasangaki et al., 2008).

\section{CONCLUSIONS}

There has been very little compliance to river Enyau bank regulation guidelines resulting into increased human activities in the protected zones of the river. These have greatly compromised the quality of the river especially along the middle zone, Ozu-Ediofe corresponding directly to Arua urban centers. Hence, more effective strategies should be put in place in Arua Municipality to strengthen the implementation of the existing river bank management guidelines in order to ensure good quality of river Enyau and its sustainability. 


\section{Acknowledgement}

Laboratory facilities and resources for this research were provided by Muni University, Biology Department. Special appreciation is due to the Department of Biology, Faculty of Science, Muni University and particularly the laboratory technician, Mr. Ssali Ibrahim for his technical support. The family members of Mr. Geofrey Oloya are acknowledged for their financial support towards the research.

\section{REFERENCES}

Abudu, D., Azo, R., \& Andogah, G. (2018). Spatial assessment of urban sprawl in Arua Municipality, Uganda. The Egyptian Journal of Remote Sensing and Space Sciences, 1-8. https://doi.org/10.1016/j.ejrs.2018.01.008

Adrapi, J. (2015). Effect of point source pollution on the quality of water in river Enyau, arua Municipality, Uganda. Retrieved May 14, 2019, from http://makir.mak.ac.ug/handle/10570/6997

Aquilina, R. (2013). Pre-restoration assessment of the Hogsmill and River Wandle. Bournemouth, UK.

Arua District Local Government. (2012). Arua District Local Government Statistical Abstract. Retrieved from https://www.ubos.org/onlinefiles/uploads/ubos/Arua.pdf

Atlas, U. W. (2016). Wetlands atlas. Kampala.

Barbour, M. T., Gerritsen, J., Snyder, B. D., \& Stribling, J. B. (1999). Rapid Bioassessment Protocols For Use in Streams and Wadeable Rivers: Periphyton, Benthic Macroinvertebrates and Fish. Washington, D.C.: U.S. Environmental Protection Agency; Office of Water.

Birmingham, M., Heimdal, D., Hubbard, T., Krier, K., Leopold, R., Neely, J., ... Wilton, T. (2005). Benthic Macroinvertebrate Key Acknowledgements. (May). Retrieved from IOWATER Volunteer Water Quality Monitoring

Chapman, D., Jackson, J., \& Krebs, F. (1996). Biological Monitoring. In J. Bartram \& R. Ballance (Eds.), Water Quality Monitoring - A Practical Guide to the Design and Implementation of Freshwater Quality Studies and Monitoring Programmes. Retrieved from http://www.who.int/water_sanitation_health/resourcesquality/wqmchap11.pdf

Clement, N., Trust, D., \& Paper, N. (2017). Effect of Water Quality on the Diversity and Distribution of Benthic Insects in Kiwunya Stream, Kampala. 5(1), 22-30.

Dickens, C. W., \& Graham, P. (2002). The South African Scoring System ( SASS ) Version 5 Rapid Bioassessment Method for Rivers. African Journal of Aquatic Science, 27(1), 1-10. https://doi.org/10.2989/16085914.2002.9626569

Du Plessis, A. (2017). Freshwater challenges of South Africa and its upper Vaal River : Global 
context of Freshwater resources. Retrieved from http://www.springer.com/978-3-31949501-9

Elhaj, M., Garbo, H., \& Chapeta, Y. (2015). Evaluating the water quality of Dura River Uganda Using Macroinvertebrate. Journal of Natural Resources and Environmental Studies, 3(11), 33-37.

Gerber, A., \& Gabriel, M. (2002a). Aquatic Invertebrates of South African Rivers. Institute for Water Quality Studies Department of Water Affairs and Forestry.

Gerber, A., \& Gabriel, M. (2002b). Aquatic invertebrates of South African rivers field guide.

Gill, K. (n.d.). Identification Guide to Freshwater Macroinvertebrates: Stroud Water Research $\begin{array}{lllll}\text { Center. } & \text { Retrieved } & \text { May } & 14, & \end{array}$ https://stroudcenter.org/MacroKey_complete.pdf\&ved

Kaaya, L. T., Day, J. A., \& Dallas, H. F. (2015). Tanzania River Scoring System ( TARISS ): a macroinvertebrate-based biotic index for rapid bioassessment of rivers. African Journal of Aquatic Science, 40(2), 109-117. https://doi.org/10.2989/16085914.2015.1051941

Kansiime, F., Muwanga, A., \& Niwagaba, C. B. (2013). Environment and Social impact Assessment ( ESIA ) For Arua Water Supply and Sanitation Project.

Kasangaki, A., Chapman, L. J., \& Balirwa, J. (2008). Land use and the ecology of benthic macroinvertebrate assemblages of high-altitude rainforest streams in Uganda. Freshwater Biology, 53(4), 681-697. https://doi.org/10.1111/j.1365-2427.2007.01925.x

Lopes, C. (2016). The Demographic Profile of African Countries. https://doi.org/978-99944-6806-5

Makoba, H., Shivoga, W., Muchiri, M., \& Miller, S. N. (2008). Use of Benthic Macroinvertebrates as Indicators of Water Quality in. 2161-2168.

Miebaka, M. (2018). Impacts of Human activities on the MacroBenthic Assemblage of a Stream in the Niger Delta, Nigeria. SF Journal of Environmental and Earth Science Nigeria. SF J Environ Earth Sci, 1(11). Retrieved from https://scienceforecastoa.com/Articles/SJEES-V1E1-1011.pdf

NER. The national environment (wetlands, river banks and lake shores management) regulations, No. 3/2000. , Pub. L. No. 1, XCIII (2000).

Odonkor, S. T., \& Addo, K. K. (2013). Bacteriological profile and physico-chemical quality of ground water: a case study of bore hole water sources in a rural Ghanaian community. International Journal of Current Microbiology and Applied Sciences, 2(8), 21-40. Retrieved from http://www.ijcmas.com

Okot-Okumu, J., Sekiranda, S. B. K., Bugenyi, F. W. ., Ndawula, L. M., \& Gandhi, P. (2004). Variation in composition of macro-benthic invertebrates as an indication of water quality 
status in three bays in Lake Victoria. Victoria, (January 2004), 396-411.

Rádková, V., Syrovátka, V., Bojková, J., Schenková, J., Křoupalová, V., \& Horsák, M. (2014). The importance of species replacement and richness in small-scale diversity patterns of aquatic macroinvertebrates in spring fens. Limnologica. https://doi.org/10.1016/j.limno.2014.03.001

Rizkiyanti, E. M., Maizar, A., \& Hertika, S. (2013). Study on Correlation of Macrozoobenthos Profusion and Pollution Level In Cinde River Batu City, Indonesia. Journal of Natural Sciences Research, 3(14), 84-92.

United Nations, Department of Economc and Social Affairs, P. D. (2015). Population 2030 Demographic challenges and opportunities for sustainable development planning (ST/ESA/SER.A/389). Retrieved from www.unpopulation.org.

USMID, U. S. to M. I. D. P. (2012). Environmental and Social System Assessment (ESSA) Background Annexes Volume 2.

Walley, W. J., \& Hawkes, H. A. (1997). A computer-based development of the Biological Monitoring Working Party score system incorporating abundance rating, site type and indicator value. Water Research, 31(2), 201-210. https://doi.org/10.1016/S00431354(96)00249-7

West Virginia Save Our Streams Field Guide to Aquatic Invertebrates. (n.d.). Retrieved from http://www.dep.wv.gov/sos

WWF, World Bank \&; NWSC in drive to save R. Enyau in Arua. (2018). Retrieved May 14, 2019, from https://wwf.panda.org/wwf_offices/uganda/?339056/WWF-WORLD-BANK-NWSC-in-drive-to-save-R-Enyau-in-Arua

Zziwa, B. J. (2012). Capacity Utilisation of National Water and Sewerage Corporation Water Supply System in Northern Uganda, A Case Study of Arua Municipality. Unpublished Dissertation, Makerere University, Kampala, Uganda. 